\title{
Communication
}

\section{The Arabidopsis MADS-Domain Transcription Factor SEEDSTICK Controls Seed Size via Direct Activation of $E 2 F a$}

\author{
Dario Paolo ${ }^{1,+}$, Lisa Rotasperti ${ }^{1}$, Arp Schnittger ${ }^{2}$, Simona Masiero ${ }^{1}$, Lucia Colombo ${ }^{1}$ and Chiara Mizzotti ${ }^{1, *} \mathbb{C}$ \\ 1 Dipartimento di BioScienze, Università degli Studi di Milano, 20133 Milano, Italy; \\ dario.paolo@ibba.cnr.it (D.P.); lisa.rotasperti@unimi.it (L.R.); simona.masiero@unimi.it (S.M.); \\ lucia.colombo@unimi.it (L.C.) \\ 2 Abteilung für Entwicklungsbiologie, Institut für Pflanzenforschung und Mikrobiologie, Universität Hamburg, \\ 22609 Hamburg, Germany; arp.schnittger@uni-hamburg.de \\ * Correspondence: chiara.mizzotti@unimi.it; Tel.: +39-02-503-14838 \\ † Present address: Institute of Agricultural Biology and Biotechnology, CNR, 20133 Milan, Italy.
}

Citation: Paolo, D.; Rotasperti, L.; Schnittger, A.; Masiero, S.; Colombo, L.; Mizzotti, C. The Arabidopsis MADS-Domain Transcription Factor SEEDSTICK Controls Seed Size via Direct Activation of E2Fa. Plants 2021, 10, 192. https://doi.org/10.3390/ plants10020192

Received: 23 December 2020

Accepted: 16 January 2021

Published: 20 January 2021

Publisher's Note: MDPI stays neutral with regard to jurisdictional claims in published maps and institutional affiliations.

Copyright: (c) 2021 by the authors. Licensee MDPI, Basel, Switzerland. This article is an open access article distributed under the terms and conditions of the Creative Commons Attribution (CC BY) license (https:// creativecommons.org/licenses/by/ $4.0 /)$.

\begin{abstract}
Seed size is the result of complex molecular networks controlling the development of the seed coat (of maternal origin) and the two fertilization products, the embryo and the endosperm. In this study we characterized the role of Arabidopsis thaliana MADS-domain transcription factor SEEDSTICK (STK) in seed size control. STK is known to regulate the differentiation of the seed coat as well as the structural and mechanical properties of cell walls in developing seeds. In particular, we further characterized stk mutant seeds. Genetic evidence (reciprocal crosses) of the inheritance of the small-seed phenotype, together with the provided analysis of cell division activity (flow cytometry), demonstrate that STK acts in the earlier phases of seed development as a maternal activator of growth. Moreover, we describe a molecular mechanism underlying this activity by reporting how STK positively regulates cell cycle progression via directly activating the expression of $E 2 F a$, a key regulator of the cell cycle. Altogether, our results unveil a new genetic network active in the maternal control of seed size in Arabidopsis.
\end{abstract}

Keywords: Arabidopsis thaliana; cell cycle; seed development; transcription factor

\section{Introduction}

In spermatophyte plants, reproductive success depends on the ability to produce healthy seeds. Indeed, seed size represents one of the major traits that influence the fitness of the next plant generation. Despite their importance, molecular regulators of seed size have only begun to be identified in the last few years, mainly through studies on Arabidopsis [1-4]. Critical factors governing seed size include the parent-of-origin effect in fertilization tissues, overall plant fertility (balance between seed size/number), cell cycle/cell expansion regulation and hormonal signaling [5-8].

The final size of Arabidopsis seeds is achieved through coordinated growth of the three parts that compose the seeds: the seed coat, the endosperm and the embryo [9]. All three parts are characterized by a different genotype: the seed coat, deriving from the ovule integuments, is entirely of maternal origin, whereas both embryo and endosperm are the result of double fertilization. In Arabidopsis, seed size is established around four days after fertilization (DAF), when the dimension of the seed cavity has reached its maximum expansion as a result of seed coat growth and endosperm proliferation [10,11].

Many factors influencing ovule and seed development have been identified [1,12]. In particular, MADS-domain transcription factors have been found to be key determinants of female reproductive development [13]. Among them, the Arabidopsis transcription factor SEEDSTICK (STK) has been largely studied in relation to its function in ovule identity determination [14,15], transmitting tract development [16,17] seed abscission [15,18], seed coat development [19] and flavonoid biosynthesis [20]. We have also previously shown 
how STK regulates size and differentiation of fruits by providing a link between signaling hormones (cytokinins) and other molecular developmental networks [21]. Loss-of-function stk mutants produce smaller seeds than wild-type, albeit with no obvious reduction in overall fertility [15]. However, the underlying molecular mechanisms of how STK promotes seed growth are not very well understood. We therefore conducted additional studies on the genetics of the small-seed phenotype of the stk mutant and we analyzed differences in mitotic activities emerging from the comparison with wild-type seeds. Moreover, we investigated possible downstream targets of STK involved in cell cycle progression. In this frame, we focused on E2Fa, a crucial transcription factor that regulates the mitotic activity of cells that is also co-expressed with STK in the seed coat of developing seeds [22-24]. The single $e 2 f a$ mutant does not have a seed-related phenotype, while the double mutant $e 2 f a / b$ has enlarged seeds, an indirect effect probably due to reduced fertility of the mutant which therefore diverts more allocated resources to the surviving seeds [24]. Here, we provide evidence of the involvement of STK in cell cycle control via the positive regulation of the expression of $E 2 F a$ in developing seeds.

\section{Results and Discussion}

\subsection{STK Maternally Controls Seed Size and Controls Cell Cycle Progression in Seeds}

To further characterize the reduction in seed size of $s t k$ seeds, we performed reciprocal crosses with wild-type plants. Our data confirmed that the smaller size and the rounder shape of stk seeds (Figure 1b,d,e) in comparison to wild-type (Figure 1a,c,e) only depend on the maternal origin of the seed coat, as suggested previously $[15,25]$. The maternally inherited small-seed phenotype of stk is also reflected in the reduction of average seed mass (Figure 1f).

(a)

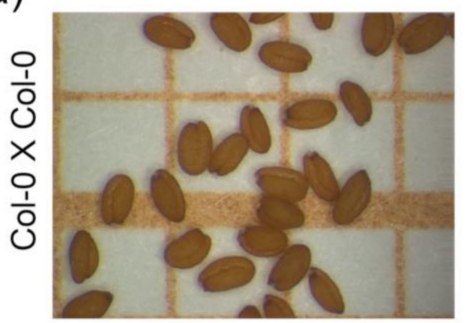

(c)

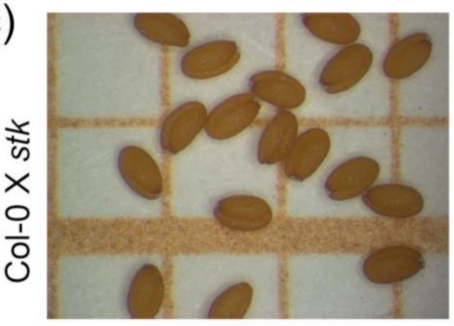

(e)

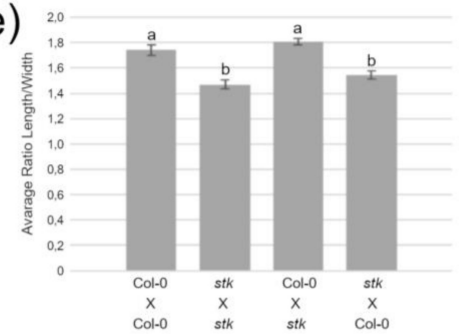

(b)

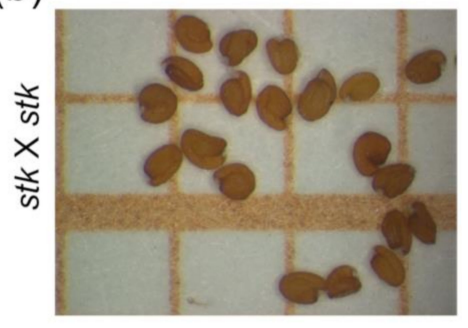

(d)

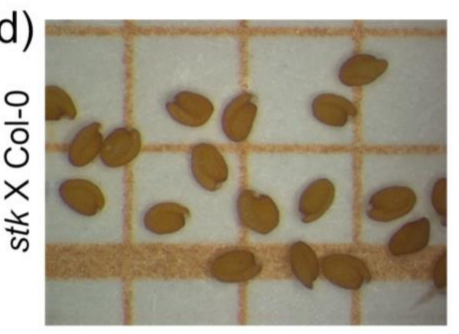

(f)

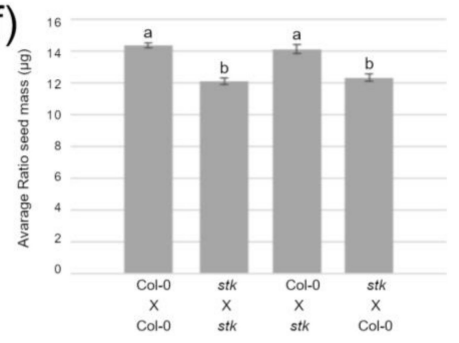

Figure 1. The phenotype of $s t k$ mutant seeds has a maternal sporophytic origin. (a-d) Seeds of reciprocal crosses between stk and wild-type Columbia (Col-0) plants on $1 \mathrm{~mm}$ squared graph paper. (e) Ratio between seed length and width. (f) Seed mass. Bars indicate means plus standard error; different letters above bars indicate statistically significant differences $(p<0.01)$. 
A key parameter of organ growth is cell number, which is determined by cell division activity. Determining the ratio between $4 \mathrm{C}$ and $2 \mathrm{C}$ cells, i.e., before and after mitosis, can give a first estimate of cell cycle activity. In young seeds $(0-6 \mathrm{DAF})$, the $4 \mathrm{C} / 2 \mathrm{C}$ ratio is mainly influenced by seed coat cells, which are the predominant fraction of cells at this time point [26].

Previous flow cytometry analyses revealed that wild-type and stk seeds differ in terms of $4 \mathrm{C}$ and $2 \mathrm{C}$ peaks [25]. In stk seeds, nearly $50 \%$ of the cells reside in the gap before mitosis, whereas this is only the case for $35 \%$ of the cells in wild-type seeds (Supplementary Figure S1). This suggests that stk mutants either progress faster through the S-phase or are slowed down in their progression through mitosis.

Next, we investigated how STK could control cell proliferation by q-PCR (Figure 2), monitoring the expression levels of known cell cycle regulators, including transcription factors, cyclins (CYC) and cyclin-dependent kinases (CDK).

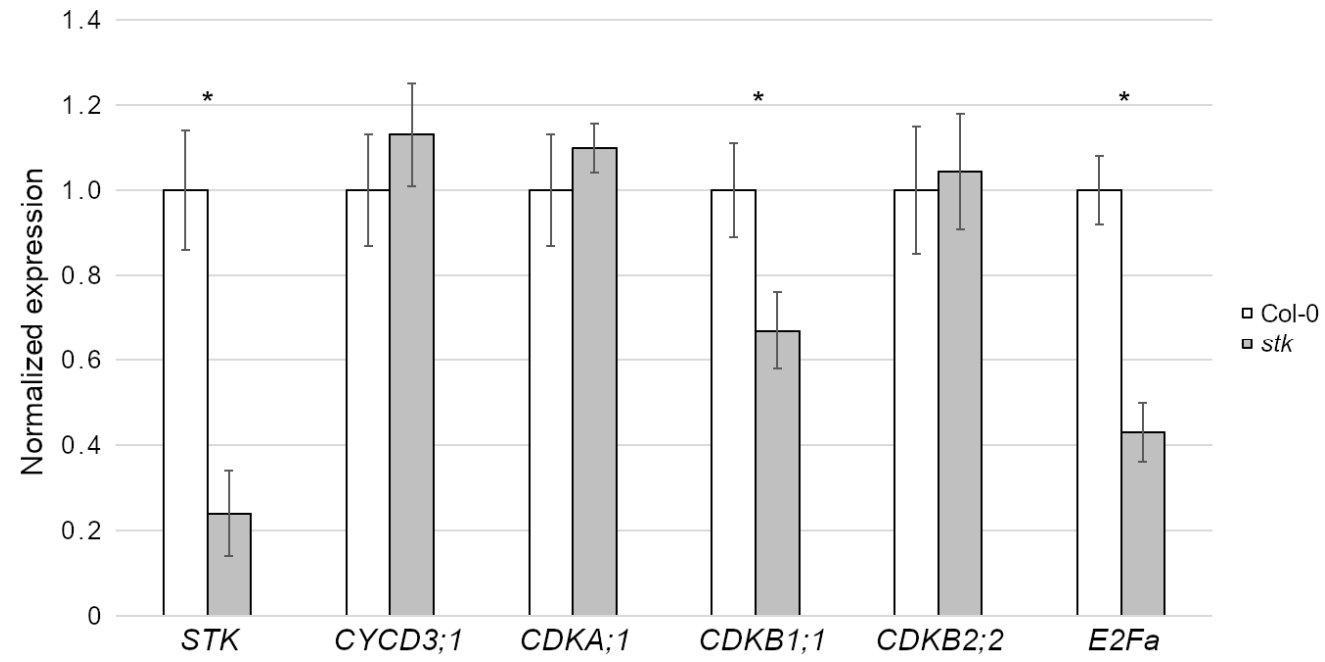

Figure 2. Expression level of cell cycle regulators in Col-0 and $s t k$ mutants. The q-PCR was conducted in triplicates using ACTIN (ACT) and UBIQUITIN (UBQ) as internal reference genes (Supplementary Table S1). Error bars represent the propagated standard deviation error value using three replicates; asterisks represent statistically significant differences $(p<0.01)$.

In Arabidopsis, the combined kinase activities of $C Y C D 3 ; 1$ and $C D K A ; 1$ constitute a major positive force of cell cycle progression [27-29]. Despite evidence of an altered cell cycle progression in the seed coat of stk seeds, as shown by the flow cytometry analysis, we did not report significant downregulation of $C Y C D 3 ; 1$ nor $C D K A ; 1$ (Figure 2). The checkpoint between the G2 and M phases is also controlled by CDKs of Type B. In particular, B1-type CDKs are characterized by maximum kinase activity during the transition from G2 to M phase, while B2-type CDKs reach their maximum activity during mitosis [30]. However, $C D K B 1 ; 1$ is only slightly downregulated in stk and $C D K B 2 ; 2$ expression is not affected in the mutant (Figure 2).

In proliferating cells, the transcription factor E2Fa acts in complex with RBR1 (RETINO BLASTOMA-RELATED PROTEIN 1) to maintain proliferation competence by inhibiting genes that control the switch from mitosis to the endocycle [31]. Moreover, similar to the STK protein, E2Fa accumulates in the nucleus of the outer integument cells [24]. For this reason, we tested the expression of $E 2 F a$ and interestingly, our analysis demonstrated that developing stk mutant seeds showed a partially reduced $E 2 F a$ expression in comparison to wild-type ones (Figure 2).

Since E2Fa-induced genes also encode proteins involved in cell wall biosynthesis, providing a possible link to STK function $[19,32,33]$, we further investigated a possible regulation of $E 2 F a$ via STK. 


\subsection{STK Directly Regulates E2Fa}

To understand the nature of $E 2 F a$ regulation via STK, we screened the $E 2 F a$ gene sequence and found two putative CaRG boxes, the CC[A/T $]_{6} \mathrm{GG}$ consensus sequences known to be recognized by the MADS-domain protein $[34,35]$ (Supplementary Figure S2). To test if $E 2 F a$ could be a direct target of STK, we performed a chromatin immunoprecipitation (ChIP) assay using an anti-STK antibody (Figure 3). As a positive control, we tested VERDANDI (VDD), a known direct target of STK [35]. Immunoprecipitated chromatin obtained from 0-4 DAF fruits was tested via q-PCR analysis, which showed that the putative binding site " $\mathrm{b}$ " of STK on E2Fa was significantly enriched over the negative control (Figure 3). This data indicates that $E 2 F a$ expression is directly regulated by STK in developing seeds by the binding to regulative region " $\mathrm{b}$ ".

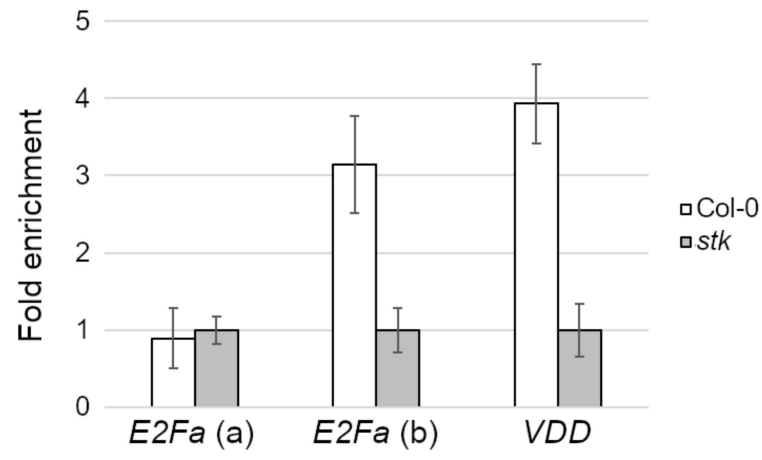

Figure 3. Chromatin immunoprecipitation (ChIP) enrichment by q-PCR of the STK binding site on $E 2 F a$. Region "b" of $E 2 F a$ (see Supplementary Figure S2) is directly bound by STK during seed development, while region "a" is not. VERDANDI (VDD) was used as positive control. The q-PCR was conducted in duplicates. Fold enrichment was calculated over the negative controls. Error bars represent the propagated error value using three replicates.

Previous studies indicate that protein complexes involved in chromatin remodeling can be recruited on target genes by transcription factors of different families, including MADS [36]. For this reason, we investigated the chromatin landscape at the confirmed STK binding site on $E 2 F a$, as we had previously done for BANYULS (BAN), another direct target of STK during the development of the seed coat [20]. This was done by means of a ChIP experiment on both wild-type and stk 0-4 DAF fruits, using a specific antibody to detect the level of H3-lysine9 acetylation (H3K9ac), an epigenetic mark usually associated with the activation of expression, choosing INDOLE ACETIC ACID-INDUCED PROTEIN 8 (IAA8) as a positive control [37]. Indeed, we revealed a lower level of H3K9ac in the stk mutant background versus the wild-type (Figure 4), in accordance with our hypothesis of a direct positive regulation of $E 2 F a$ expression levels by STK.

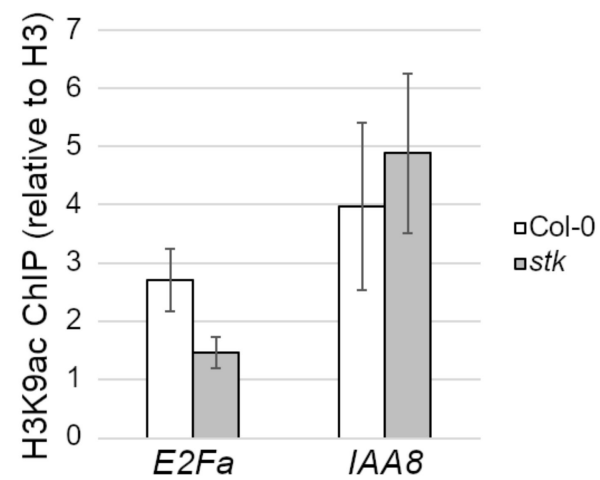

Figure 4. ChIP enrichment tests by q-PCR of H3-lysine9 acetylation (H3K9ac) level in E2Fa region " $\mathrm{b}$ " of wild-type and stk samples expressed as \% input, normalized on total H3 level with error bars representing the propagated error value using three replicates. IAA8 was used as positive control. 


\section{Conclusions}

Based on our previous analyses $[20,25]$ and the data presented here, we propose that STK controls cell cycle progression in the developing seed coat.

This mechanism involves the positive regulation of $E 2 F a$. We also found that $C D K B 1 ; 1$ expression is reduced and interestingly, the promoter of $C D K B 1 ; 1$ is bound and regulated by $\mathrm{E} 2 \mathrm{Fa}$ [38]. The activation of $E 2 \mathrm{Fa}$ likely involves local epigenetic remodeling of chromatin, as seen by the reduction in open and active chromatin at the STK-bound E2Fa locus in stk mutants. Thus, the regulation of ovule and seed development by STK expands to cell proliferation control, opening a new facet of MADS-domain transcription factors' action during reproduction.

\section{Materials and Methods}

\subsection{Plant Material and Growth Condition}

Arabidopsis thaliana wild-type (ecotype Columbia, Col-0) and stk mutant lines were grown on soil at $22{ }^{\circ} \mathrm{C}$ (3-6 plants per pot), initially in growth chambers under short-day conditions ( $8 \mathrm{~h}$ light $/ 16 \mathrm{~h}$ dark) for two weeks and then moved to an experimental greenhouse under long-day conditions ( $16 \mathrm{~h}$ light $/ 8 \mathrm{~h}$ dark). stk mutant lines are homozygous for the stk-2 allele, which contains a 74 nucleotide insertion near the splice site of the 3rd intron; stk seeds were obtained by M. Yanosfky's lab [15].

\subsection{Genotyping}

PCR-based genotyping for mutant alleles was performed with the primers listed in Supplementary Table S1 with the following conditions: $95^{\circ} \mathrm{C} 3^{\prime}, 35$ cycles of $95^{\circ} \mathrm{C} 30^{\prime \prime}$ $+61^{\circ} \mathrm{C} 30^{\prime \prime}+72{ }^{\circ} \mathrm{C} 30^{\prime \prime}, 72^{\circ} \mathrm{C} 5^{\prime}$ and PCR products were checked on ethidium bromidestained $1 \%$ agarose gel in $1 \times$ TAE (Tris base, acetic acid and EDTA buffer).

\subsection{Seed Analysis}

Seeds were photographed using a Leica MZ6 stereomicroscope, and seed images $(n=25)$ were measured using ImageJ software. Average seed mass was determined by weighing mature dry seeds in batches of 500 and the weights of at least three replicates were measured for each seed lot. Measurements were statistically analyzed by one-way ANOVA with post-hoc Tukey honestly significant difference (HSD) comparison test and statistical differences marked as different letters reflect $p<0.01$.

\subsection{Ploidy Analysis}

For flow cytometry analysis, flowers were emasculated $24 \mathrm{~h}$ before manual pollination with pollen of the same genotype. Seeds were collected from the siliques at 6 DAF and prepared for analysis using the CyStain ${ }^{\circledR}$ UV Precise kit (Partec, Cat. 05-5002). The staining with DAPI (4',6-diamidino-2-phenylindole) was performed as previously described [39]. The ploidy level was calibrated against the $2 \mathrm{C}$ nuclear DNA content peak derived from a preparation of young rosette leaves [25].

\subsection{Expression Analyses}

Total RNA was extracted in triplicate from flowers and siliques until 4 DAF using the $\mathrm{LiCl}$ method [40]. Total RNA was treated using Ambion TURBO DNA-free ${ }^{\mathrm{TM}}$ DNase (Ambion, Cat. AM1907) and then reverse transcribed using the Bio-Rad iScript ${ }^{\mathrm{TM}}$ kit (Bio- $^{-}$ Rad, Cat. 170-8891). q-PCR was performed on three biological samples and on technical triplicates using the iQ5 real-time PCR detection system (Bio-Rad) in $20 \mu \mathrm{L}$ reactions with $250 \mathrm{nM}$ of each primer and the SYBR Green PCR Master Mix (Bio-Rad). The 3-step amplification protocol used was $95^{\circ} \mathrm{C} 3^{\prime}$ followed 40 cycles of $95^{\circ} \mathrm{C} 10^{\prime \prime}+60^{\circ} \mathrm{C} 30^{\prime \prime}$, with melt curves calculated over the $60-95{ }^{\circ} \mathrm{C}$ interval with $+0.5^{\circ} \mathrm{C}$ increments. cDNA was standardized relative to UBIQUITIN (UBQ) and ACTIN (ACT) transcript levels and gene expression analysis was performed with the $2^{\wedge}-\Delta \Delta \mathrm{Ct}$ method using Bio-Rad CFX Maestro software v.4.0 (Bio-Rad). Baseline and threshold levels were set according to the 
manufacturer's instructions. Student's $t$-tests were run for each experiment and asterisks indicate significant differences $(p<0.01)$. The primers used in these experiments are listed in Supplementary Table S1.

\subsection{Chromatin Immunoprecipitation Assay}

ChIP experiments to evaluate the enrichment of E2Fa were performed with an antibody specific for the STK protein on fertilized flowers and siliques until 4 DAF. Plant material was collected from wild-type (Col-0) and stk plants. The q-PCR assay was conducted on biological duplicates, with three technical replicates for each sample. The q-PCR protocols used were the same as those listed in Section 4.5 of this manuscript. Data were obtained using the iQ5 real-time PCR detection system (Bio-Rad) with the SYBR Green PCR Master Mix (Bio-Rad) and, for the region of interest, fold enrichment over negative control $(A C T)$ was evaluated with a method previously reported using $V D D$ as a positive control [35].

Similarly, relative differences in acetylation levels between the wild-type (Col-0) and the stk mutant were tested by ChIP using the same developmental stages mentioned above. We used an antibody against an unmodified isoform of H3 ("total H3", Upstate, Cat. 06-753) and one specific for H3K9ac (Upstate, Cat. 07-532). For each sample, the percentage of enrichment in the acetylation versus input was calculated as previously shown [41], normalizing for total H3. IAA8 was used as a positive control [20]. The primers used in these experiments are listed in Supplementary Table S1.

Supplementary Materials: The following are available online at https: / www.mdpi.com/2223-7 747/10/2/192/s1, Figure S1: DNA-content profile obtained from flow cytometry analysis of seeds; Figure S2: Schematic representation of the E2Fa gene; Table S1: List of primers.

Author Contributions: Conceptualization: D.P., L.C. and C.M.; formal analysis: D.P., L.R. and C.M.; supervision and funding acquisition: A.S., S.M. and L.C.; writing—original draft preparation: D.P. and C.M.; writing-review and editing: D.P. and C.M. All authors have read and agreed to the published version of the manuscript.

Funding: This work was supported by a fellowship from the Università degli Studi di Milano (D.P.) and by European Cooperation in Science and Technology (COST) Action FA0903 (D.P and L.C.).

Data Availability Statement: The data presented in this study are available on request from the corresponding author.

Acknowledgments: The authors would like to thank L. Dreni, F. Galbiati and I. Ezquer for their preliminary assistance in conceptualization and data analysis and A. Cavalleri for critical reading of the manuscript, as well as V. Parravicini and M. Beretta for their technical assistance.

Conflicts of Interest: The authors declare no conflict of interest.

\section{References}

1. Orozco-Arroyo, G.; Paolo, D.; Ezquer, I.; Colombo, L. Networks controlling seed size in Arabidopsis. Plant Reprod. 2015, 28, 17-32. [CrossRef]

2. Li, N.; Li, Y. Signaling pathways of seed size control in plants. Curr. Opin. Plant Biol. 2016, 33, 23-32. [CrossRef]

3. Li, N.; Li, Y. Maternal control of seed size in plants. J. Exp. Bot. 2015, 66, 1087-1097. [CrossRef]

4. Li, N.; Xu, R.; Li, Y. Molecular Networks of Seed Size Control in Plants. Annu. Rev. Plant Biol. 2019, 70, 435-463. [CrossRef]

5. Haig, D. Kin conflict in seed development: An interdependent but fractious collective. Annu. Rev. Cell Dev. Biol. 2013, $29,189-211$. [CrossRef]

6. Hughes, R.; Spielman, M.; Schruff, M.C.; Larson, T.R.; Graham, I.A.; Scott, R.J. Yield assessment of integument-led seed growth following targeted repair of auxin response factor 2. Plant Biotechnol. J. 2008, 6, 758-769. [CrossRef]

7. Jiang, W.-B.; Lin, W.-H. Brassinosteroid functions in Arabidopsis seed development. Plant Signal. Behav. 2013, 8, e25928. [CrossRef]

8. Zhang, B.; Li, C.; Li, Y.; Yu, H. Mobile TERMINAL FLOWER1 determines seed size in Arabidopsis. Nat. Plants 2020, 6, $1146-1157$. [CrossRef]

9. Nowack, M.K.; Ungru, A.; Bjerkan, K.N.; Grini, P.E.; Schnittger, A. Reproductive cross-talk: Seed development in flowering plants. Biochem. Soc. Trans. 2010, 38, 604-612. [CrossRef] 
10. Sun, X.; Shantharaj, D.; Kang, X.; Ni, M. Transcriptional and hormonal signaling control of Arabidopsis seed development. Curr. Opin. Plant Biol. 2010, 13, 611-620. [CrossRef]

11. Sundaresan, V. Control of seed size in plants. Proc. Natl. Acad. Sci. USA 2005, 102, 17887-17888. [CrossRef]

12. Cucinotta, M.; Colombo, L.; Roig-Villanova, I. Ovule development, a new model for lateral organ formation. Front. Plant Sci. 2014, 5, 117. [CrossRef]

13. Masiero, S.; Colombo, L.; Grini, P.E.; Schnittger, A.; Kater, M.M. The emerging importance of type I MADS box transcription factors for plant reproduction. Plant Cell 2011, 23, 865-872. [CrossRef]

14. Favaro, R.; Pinyopich, A.; Battaglia, R.; Kooiker, M.; Borghi, L.; Ditta, G.; Yanofsky, M.F.; Kater, M.M.; Colombo, L. MADS-box protein complexes control carpel and ovule development in Arabidopsis. Plant Cell 2003, 15, 2603-2611. [CrossRef]

15. Pinyopich, A.; Ditta, G.S.; Savidge, B.; Liljegren, S.J.; Baumann, E.; Wisman, E.; Yanofsky, M.F. Assessing the redundancy of MADS-box genes during carpel and ovule development. Nature 2003, 424, 85-88. [CrossRef]

16. Di Marzo, M.; Roig-Villanova, I.; Zanchetti, E.; Caselli, F.; Gregis, V.; Bardetti, P.; Chiara, M.; Guazzotti, A.; Caporali, E.; Mendes, M.A.; et al. MADS-Box and bHLH Transcription Factors Coordinate Transmitting Tract Development in Arabidopsis thaliana. Front. Plant Sci. 2020, 11, 526. [CrossRef]

17. Herrera-Ubaldo, H.; Lozano-Sotomayor, P.; Ezquer, I.; Di Marzo, M.; Chávez Montes, R.A.; Gómez-Felipe, A.; Pablo-Villa, J.; Diaz-Ramirez, D.; Ballester, P.; Ferrándiz, C.; et al. New roles of NO TRANSMITTING TRACT and SEEDSTICK during medial domain development in Arabidopsis fruits. Development 2019, 146. [CrossRef]

18. Balanzà, V.; Roig-Villanova, I.; Di Marzo, M.; Masiero, S.; Colombo, L. Seed abscission and fruit dehiscence required for seed dispersal rely on similar genetic networks. Development 2016, 143, 3372-3381. [CrossRef]

19. Ezquer, I.; Mizzotti, C.; Nguema-Ona, E.; Gotté, M.; Beauzamy, L.; Viana, V.E.; Dubrulle, N.; De Oliveira, A.C.; Caporali, E.; Koroney, A.-S.; et al. The developmental regulator SEEDSTICK controls structural and mechanical properties of the arabidopsis seed coat. Plant Cell 2016, 28, 2478-2492. [CrossRef]

20. Mizzotti, C.; Ezquer, I.; Paolo, D.; Rueda-Romero, P.; Guerra, R.F.; Battaglia, R.; Rogachev, I.; Aharoni, A.; Kater, M.M.; Caporali, E.; et al. SEEDSTICK is a Master Regulator of Development and Metabolism in the Arabidopsis Seed Coat. PLoS Genet. 2014, 10, 1-15. [CrossRef]

21. Di Marzo, M.; Herrera-Ubaldo, H.; Caporali, E.; Novák, O.; Strnad, M.; Balanzà, V.; Ezquer, I.; Mendes, M.A.; De Folter, S.; Colombo, L. SEEDSTICK Controls Arabidopsis Fruit Size by Regulating Cytokinin Levels and FRUITFULL. Cell Rep. 2020, 30, 2846-2857.e3. [CrossRef]

22. Vlieghe, K.; Boudolf, V.; Beemster, G.T.S.; Maes, S.; Magyar, Z.; Atanassova, A.; de Almeida Engler, J.; De Groodt, R.; Inzé, D.; De Veylder, L. The DP-E2F-like gene DEL1 controls the endocycle in Arabidopsis thaliana. Curr. Biol. 2005, 15, 59-63. [CrossRef]

23. Sozzani, R.; Maggio, C.; Varotto, S.; Canova, S.; Bergounioux, C.; Albani, D.; Cella, R. Interplay between Arabidopsis activating factors E2Fb and E2Fa in cell cycle progression and development. Plant Physiol. 2006, 140, 1355-1366. [CrossRef]

24. Leviczky, T.; Molnár, E.; Papdi, C.; Ôszi, E.; Horváth, G.V.; Vizler, C.; Nagy, V.; Pauk, J.; Bögre, L.; Magyar, Z. E2FA and E2FB transcription factors coordinate cell proliferation with seed maturation. Development 2019, 146, dev179333. [CrossRef]

25. Mizzotti, C.; Mendes, M.A.; Caporali, E.; Schnittger, A.; Kater, M.M.; Battaglia, R.; Colombo, L. The MADS box genes SEEDSTICK and ARABIDOPSIS Bsister play a maternal role in fertilization and seed development. Plant J. 2012, 70, 409-420. [CrossRef]

26. Boudolf, V.; Vlieghe, K.; Beemster, G.T.S.; Magyar, Z.; Torres Acosta, J.A.; Maes, S.; Van Der Schueren, E.; Inze, D.; De Veylder, L. The plant-specific cyclin-dependent kinase CDKB1;1 and transcription factor E2Fa-DPa control the balance of mitotically dividing and endoreduplicating cells in Arabidopsis. Plant Cell 2004, 16, 2683-2692. [CrossRef]

27. Harashima, H.; Schnittger, A. Robust reconstitution of active cell-cycle control complexes from co-expressed proteins in bacteria. Plant Methods 2012, 8, 1-9. [CrossRef]

28. Schnittger, A.; Schöbinger, U.; Bouyer, D.; Weinl, C.; Stierhof, Y.-D.; Hülskamp, M. Ectopic D-type cyclin expression induces not only DNA replication but also cell division in Arabidopsis trichomes. Proc. Natl. Acad. Sci. USA 2002, 99, 6410-6415. [CrossRef]

29. Dewitte, W.; Riou-Khamlichi, C.; Scofield, S.; Healy, J.M.S.; Jacqmard, A.; Kilby, N.J.; Murray, J.A.H. Altered cell cycle distribution, hyperplasia, and inhibited differentiation in Arabidopsis caused by the D-type cyclin CYCD3. Plant Cell 2003, 15, 79-92. [CrossRef]

30. Inze, D.; De Veylder, L. Cell cycle regulation in plant development. Annu. Rev. Genet. 2006, 40, 77-105. [CrossRef]

31. Magyar, Z.; Horváth, B.; Khan, S.; Mohammed, B.; Henriques, R.; De Veylder, L.; Bakó, L.; Scheres, B.; Bögre, L. Arabidopsis E2FA stimulates proliferation and endocycle separately through RBR-bound and RBR-free complexes. EMBO J. 2012, 31, 1480-1493. [CrossRef]

32. Vlieghe, K.; Vuylsteke, M.; Florquin, K.; Rombauts, S.; Maes, S.; Ormenese, S.; Van Hummelen, P.; Van de Peer, Y.; Inze, D.; De Veylder, L. Microarray analysis of E2Fa-DPa-overexpressing plants uncovers a cross-talking genetic network between DNA replication and nitrogen assimilation. J. Cell Sci. 2003, 116, 4249-4259. [CrossRef]

33. De Jager, S.M.; Scofield, S.; Huntley, R.P.; Robinson, A.S.; den Boer, B.G.W.; Murray, J.A.H. Dissecting regulatory pathways of G1/S control in Arabidopsis: Common and distinct targets of CYCD3;1, E2Fa and E2Fc. Plant Mol. Biol. 2009, 71, 345-365. [CrossRef]

34. Nurrish, S.; Treisman, R. DNA binding specificity determinants in MADS-box transcription factors. Mol. Cell. Biol. 1995, 15, 4076-4085. [CrossRef] 
35. Matias-Hernandez, L.; Battaglia, R.; Galbiati, F.; Rubes, M.; Eichenberger, C.; Grossniklaus, U.; Kater, M.M.; Colombo, L. VERDANDI is a direct target of the MADS domain ovule identity complex and affects embryo sac differentiation in Arabidopsis. Plant Cell 2010, 22, 1702-1715. [CrossRef]

36. Hill, K.; Wang, H.; Perry, S.E. A transcriptional repression motif in the MADS factor AGL15 is involved in recruitment of histone deacetylase complex components. Plant J. 2008, 53, 172-185. [CrossRef]

37. Lauria, M.; Rossi, V. Epigenetic control of gene regulation in plants. Biochim. Biophys. Acta 2011, 1809, 369-378. [CrossRef]

38. Nowack, M.K.; Harashima, H.; Dissmeyer, N.; Zhao, X.; Bouyer, D.; Weimer, A.K.; De Winter, F.; Yang, F.; Schnittger, A. Genetic framework of cyclin-dependent kinase function in Arabidopsis. Dev. Cell 2012, 22, 1030-1040. [CrossRef]

39. Nowack, M.K.; Shirzadi, R.; Dissmeyer, N.; Dolf, A.; Endl, E.; Grini, P.E.; Schnittger, A. Bypassing genomic imprinting allows seed development. Nature 2007, 447, 312-315. [CrossRef]

40. Verwoerd, T.C.; Dekker, B.M.; Hoekema, A. A small-scale procedure for the rapid isolation of plant RNAs. Nucleic Acids Res. 1989, 17, 2362. [CrossRef]

41. Lin, X.; Tirichine, L.; Bowler, C. Protocol: Chromatin immunoprecipitation (ChIP) methodology to investigate histone modifications in two model diatom species. Plant Methods 2012, 8, 1-9. [CrossRef] 